\title{
Discussion: Asphalt for dam engineering
}

Roger Smith BSC

Director, Hesselberg Hydro (1991) Ltd, Folkestone, Kent, UK (rsmith@hesselberg-hydro.com)

Firstly, I would like to thank Alan Warren for writing about the use of asphalt in dam engineering. The paper gives an excellent overview of the use of dense asphaltic concrete (DAC) for waterproofing dams, the original type of asphalt used in dam engineering. Secondly, I would like to bring the readers' attention to other more recent developments in the use of asphalt products in dam engineering.

Hesselberg Hydro was formed in 1986 to service the dam waterproofing market, and installed several linings and cores, including the DAC core for the Queen's Valley Reservoir, Jersey in 1990/1991. During discussions at Queen's Valley with Rod Bridle, we became aware of the increasing problem of deteriorating upstream faces on old Pennine Dams. This led us to use our experiences with asphalt in coastal engineering to provide a solution for the upstream faces against wave attack. We suggested using an Open Stone Asphalt (OSA) layer to stabilise the steep rock slope below the spillweir at Winscar Dam - a proposal that was accepted and installed in 1991 (Bridle and Robertshaw, 1994).

After assessing the performance of the OSA for several years, Yorkshire Water commissioned further projects in 1995 and on many other dams, with the most recent in 2018.

Another pioneering project in 1997/1998 saw a product proven in coastal engineering, bituminous grouted rock, used to stabilise the rip-rap layer protecting the upstream face of the Megget dam in the Scottish borders (Gallacher et al., 1998).

In 2001 OSA was used to protect spillways for the first time and since then several more have been installed, including the Chapelton dam near Elgin in Scotland (Gowens et al., 2010).

Since 1991 Hesselberg Hydro has worked on over 50 dams in the UK (see https://www.hesselberg-hydro.com/projects/), and has worked for most of the major water companies and the Environment Agency. While the main use of OSA is for strengthening existing upstream faces, it is also specified for new revetments on new or enlarged reservoirs. With a lower carbon footprint than concrete, asphalt is a suitable alternative to concrete blocks.

\section{REFERENCES}

Bridle A and Robertshaw A (1994) Open stone asphalt wave protection dams. Dams and Reservoirs 4(3): 22.

Gallacher D, Doake RM and Hay-Smith D (1998) Remedial works to upstream face protection, Megget reservoir. In The Prospect for Reservoirs in the 21st Century (Tedd P (ed.)). Thomas Telford, London, UK, pp. 342-358.

Gowens I, Moysey D and Winfield P (2010) Chapelton flood storage reservoir. In Managing Dams - Challenges in a Time of Change (Pepper AT (ed.)). Thomas Telford, London, UK, pp. 376-387. 